\title{
Korean Clubs in the United Arab Emirates: Promoting Intercultural Competence of Female Emiratis
}

\author{
Robyn Albers, Hessa Rashed AINuaimi
}

Zayed University, Abu Dhabi, United Arab Emirates

Objectives: The significant impact that Hallyu (the "Korean Wave") has recently been having on young female Emiratis can be seen in the recent trend of female Emirati university students joining Korean clubs to learn more about the culture. The women are first attracted to the culture by Korean pop music (K-pop) and Korean dramas (K-dramas) and then become more interested in learning about Korean culture and language. The purpose of this study is to show how a university Korean club and the Korean Cultural Center in the United Arab Emirates (UAE) provide the experiential perspectives necessary to gain intercultural competence and an appreciation for Korean culture.

Methods: We surveyed 23 female Korean Club members in the UAE to understand why they are interested in Korean culture and analyzed the winning speech of the 2019 Korean speech contest to see if students had gained intercultural communication competence and an appreciation for Korean culture.

Results: We found that Emirati females are initially drawn to Korean culture by Hallyu, specifically by Korean pop music and dramas. The students then become interested in learning the Korean language and other opportunities to learn more about Korea. Involvement in university Korean clubs helps students immerse themselves in Korean culture and language while living in the UAE. Conclusion: The strong interest in Korea coupled with Korean cultural experiences within the UAE is creating culturally competent students who are ready to join the workforce. Arab students capable of speaking Arabic, English, and Korean fluently with an understanding of Korean culture will benefit the on-going bilateral relations between the UAE and Korea.

Key Words: Intercultural Communication, Korea-UAE Communication, Korean Clubs, Experiential Learning, Female Emiratis

\section{Introduction}

\section{Hallyu in the United Arab Emirates}

Since the mid-2000s, the United Arab Emirates (UAE) and

Received: Oct 2, 2019 Revised: Nov 27, 2019 Accepted: Dec 5, 2019

Corresponding author: Robyn Albers

College of Business, Zayed University, Abu Dhabi, PO Box 144534,

United Arab Emirates

Tel: +971-2-599-3231, E-mail: Robyn.albers@zu.ac.ae

This is an Open Access article distributed under the terms of the Creative Commons Attribution Non-Commercial License (http://creativecommons.org/licenses/ by-nc/4.0/) which permits unrestricted non-commercial use, distribution, and reproduction in any medium, provided the original work is properly cited.

Copyright $\odot 2020$ Korean Association for Business Communication.
South Korea have been developing stronger ties that go beyond the construction and energy sectors that originally united them (Jeong, 2019). Jeong (2019) writes that the UAE and Korea have been broadening their bilateral ties in security and defense, innovation, and food security. A newspaper in the UAE recently reported that the bilateral trade between the two countries is valued at 15 billion dollars. According to Ahmad (2020), "Korean exports to the UAE include automobiles, construction materials and electronics, including mobile phones and televisions, while UAE exports petrochemical products, such as oil."

The bilateral ties between the UAE and Korea are strong in terms of products, but Jeong (2019) also notes that one of the areas of this relationship that have developed is cultural exchanges 
in the UAE. Jeong (2019) explains how Hallyu, also known as the Korean Wave, has made its mark in the UAE through Korean pop music (K-pop) and dramas (K-dramas). Swan (2019) explains that Emirati females enjoy K-dramas more than Hollywood or Bollywood movies because the two societies share similar values. For example, the content and language are more conservative and show a stronger emphasis on family values.

Further evidence of Hally $u$ has also been seen with the introduction of the Korean Cultural Center (2020) that opened in the UAE capital of Abu Dhabi in 2016. According to the Korean Cultural Center's website, the focus is on strengthening the relationships between the two countries through food, Taekwondo, art, and Korean language instruction (Korean Cultural Center, 2019). Swan (2019) writes that many Emirati female students are learning Korean to further immerse themselves in the culture. They take lessons through the Korean Cultural Center or study the language through YouTube videos. Hallyu has also shown its power within universities across the UAE.

\section{Korean Clubs in the UAE}

According to Jeong (2019), there are nine Korean clubs presently active in UAE universities. One example of a Korean Club is at Zayed University in Abu Dhabi. It was founded in 2008 and celebrates Korean culture, traditions, and entertainment. Due to the growing phenomenon of Hallyu, the number of members in this Korean club has been increasing, reaching up to 150 members on their Facebook page and 250 members on their Instagram page. Their activities have included a number of successful events such as the welcoming of Won Ho Chung, a wellknown Korean-Vietnamese comedian based in the Middle East.

On March 13, 2011, the Korean Club held its first Korean day, which was attended by the former First Lady of South Korea, Kim Yoon Ok. The Korean Club had the honor of giving the First Lady a campus tour as well as having her participate in a Korean cooking class with the club members (Huang, 2011). According to their official Instagram page, the Korean club also hosted events that allowed its members to participate in a 'Mafia Game' inspired by the Korean variety show "Mafia Game in Prison" as well as a "Movie Day" that showcased the wellknown Korean movie The Dude Inside Me.

The club also held the Korea Festival 2018, or the 'Day of Jeonbuk' Festival. This event was hosted attended by Noura bint Mohammed Al Kaabi, the Minister of Culture \& Knowledge Development and the President of Zayed University together with, Park Kang Ho, the Ambassador of the Republic of Korea, and other Korean representatives (Zayed University, 2018). The Korea Festival 2018 included several cultural activities, including traditional music and dances by the Namwon $\mathrm{Mu}$ - sic Orchestra, a bibimbap tutorial, as well as a showcase of the club members' Korea-related talents, such as drawing Korean cartoon characters, calligraphy, traditional cooking booths, and communicating in Korean with Korean officials and guests (Zayed University, 2018).

These types of activities provide students with the necessary experiential perspectives of intercultural communication discussed by Crossman and Bordia (2012), who argue that the "transfer of theoretical knowledge to the work context can best happen through experiential learning." Theoretical knowledge often comes from textbooks or journal articles such as the scholarly works of Hall and Hall (1990) and Hofstede (2001), which are traditionally taught in business schools today. For example, Hofstede discusses collectivism, the notion of a society prioritizing or valuing the group over the individual, as one of his cultural dimensions. Both the UAE and South Korea are low on the individualism dimension and are indexed at 25 and 18 respectively (Hofstede, 2019). Students learn about the different dimensions of culture from textbooks, but according to Crossman and Bordia (2012), the activities provided by Korean clubs and Korean Cultural Centers give students in those clubs a frame of reference to better understand these theories.

The aim of this case report is to suggest that Korean clubs and activities supported by Korean Cultural Centers give students the experiential perspectives necessary to gain intercultural competence.

\section{Methods}

For this study, female Emirati students from the Korean club at Zayed University were invited to fill out a survey about their interest in South Korea and indicate why they joined the club. There were 11 questions included in the survey (see Appendix 1) with three open ended options. Data was collected from 23 completed surveys. The study also collected data from the winning speech of $7^{\text {th }}$ annual Korean speech contest hosted by the Korean Cultural Center, which was hosted in October 2019 in Abu Dhabi. The topic was linked to the UAE's year of tolerance, and participants were asked to talk about "mutual understanding and respect between Korea and the UAE" (Korean Cultural Center, 2019). The speech was translated into English and analyzed for evidence of intercultural competence from an experiential perspective.

\section{Results}

\section{Influence from Hallyu}

The results from the survey confirm Jeong's (2019) assertion 
that the Hallyu has been successful in the UAE. When asked on the survey, "What is the \#1 reason for your love of Korea?" the majority of the respondents (78\%) chose K-pop as their answer. The club members listed their three favorite Korean male and female singing groups. The results were BTS, EXO, and GOT7 for the male groups, and Blackpink, Mamamoo, and 2NE1 for the female groups. The second most common reason for their love of Korea was K-dramas at $65 \%$ and food, following at $22 \%$. The most popular K-dramas were Goblin, Descendants of the Sun, and Healer.

\section{The Korea Club}

The survey also asked students to state how long they had been in the club, what drew them to the club, and how proficient they were in the Korean language. The majority of the respondents (52\%) indicated they had been a member for less than a year, and $30 \%$ had been a member for less than two years. This is a normal turnover rate, as the students are enrolled in a four-year program. Only four of the respondents had been in the club for more than two years. However, despite their short amount of time in the club, $65 \%$ of the respondents indicated they had been interested in Korea for more than four years.

The survey also provided an open-ended question about why students had joined the Korea club, and 20 of the 23 respondents chose to answer this question, with some respondents choosing to give more than one answer. The survey shows that $85 \%$ of the students joined the Korean club because they wanted to learn more about Korean culture, with learning the language (25\%) and talking about K-pop (25\%) being the next most common reason. Other answers included their love of the country, the fun nature of the club, their love of K-dramas, and their friends joining the club. The results showed that the majority of the club members had only a beginning proficiency in the Korean language.

\section{Learning the Korean Language}

All of the students were learning how to speak Korean in an 8-level program offered by the King Sejong Institute in the Korean Culture Centre located in Abu Dhabi. This is a program that teaches and trains students in Korean reading, writing, listening, and speaking. Levels $1 \& 2$ are considered 'Beginner', Levels 3 \& 4 'Elementary', Levels 5 \& 6 'Intermediate', and Levels $7 \& 8$ 'Advanced.' Level 1 of the program starts by teaching students the basics of the language, including the alphabet (Hangul), native Korean and Sino-Korean numerical systems, and basic vocabulary and grammar. A student reaching Level 8 is considered to have completed the program.

The 8-level program prepares students for the TOPIK (Test of
Proficiency in Korean, 2020), which is a test that allows non-native speakers of Korean to attain a TOPIK certificate. This certificate is useful for a number of endeavors that would interest students. Students can use a TOPIK certificate to apply for the Korean Government Scholarship Program (KGSP), entrance into Korean universities as an international student, employment in the public and private sector for companies in South Korea and the UAE. The survey results show that $58 \%$ of the students were in Level 1 and that 19\% had reached Level 2. 15\% of the respondents had reached Level 4 , and $8 \%$ had reached Level 6. The students continue to learn Korean and aspire to improve their Korean proficiency.

\section{Speech Contest Results}

The content of the winning speech was used as qualitative data to analyze whether experiential perspectives from the Korean club and the Korean Cultural Center helped students gain intercultural competence that would bridge the cultures of the UAE and Korea. The topic of the contest was "mutual understanding and respect between Korea and the UAE." It was translated from Arabic to Korean and English by the speech writer. Evidence in the following excerpt shows that the student is engaged in intercultural communication.

The excerpt indicates that these Korean friends wanted to know more about romantic relationships and how men and women meet in the UAE. The student analyzed what she knew about dating practices in Korea based on what she had learned from K-dramas. She was aware that Korean couples often meet on blind dates or organize dates themselves at coffee shops or parks. The student approached this difference without judgement and was able to compare her culture with Korean culture. She pointed out that in Emirati culture, couples most commonly meet through arranged marriages. She wrote, "In our culture, when parents, especially the man's mother meets someone who she thinks her son would like and is fit for marriage, the two families meet and start getting to know each other." The student is able to recognize different approaches to dating and marriage; however, despite those differences, she points out that both cultures place great importance on parental approval. She references this similarity in the following quote:

\section{Excerpt 1. Sample content of the winning speech}

I often talk to my Korean friends who live in the UAE, in a Kakao talk group chat. I was curious to find out what taboo topics of Emirati culture they would like to know more about, but never got the chance to have a conversation about. 
It may seem like a big cultural difference but, in both the Emirati and Korean Culture, we respect and love our families; and we value and honor them. So, for us we trust that our parents and family would make the right judgment of finding the most compatible person as our partner.

\section{Discussion}

The results show that Emirati students are first attracted to Korea primarily because of K-pop and K-dramas. The students are initially interested in K-pop and K-dramas because of the shared values between the two societies. Hofstede's theory of cultural dimensions shows that both Korea and the UAE are collectivist and place a high degree of importance on the family or group.

Evidence from this case study shows that the speech contest winner recognized that both cultures were similar in their deep respect for parents and their love for family (Appendix 2). She did not, however, use theoretical terms to describe these similarities. Crossman and Bordia's (2012) suggestion that experiential learning helps students transfer theoretical knowledge to a practical context is thus supported. It is through watching $\mathrm{K}$-dramas and talking to members of the Korean club and Korean friends in a Kakao group chatroom that the speech contest winner and club members were able to appreciate and strengthen their understanding of intercultural theory.

Providing cultural opportunities for students to engage in gives students the necessary experiential perspectives of intercultural communication discussed by Crossman and Bordia (2012). It is interesting to note that Korea and the UAE continue to strengthen these bilateral ties described by Jeong (2019). On January 20, 2020, the Gulf News reported that the UAE and the Republic of Korea celebrated the 40-year anniversary of diplomatic relations. The two countries launched a year-long series starting in January 2020 of "events, workshops and public talks that celebrate and recognize Korean and Emirati culture in both countries" (2020). Noura Al Kaabi, Minister of Culture and Knowledge Development, said that she was looking forward to "nurturing young talent and encouraging a future generation of cultural creators, artists and leaders" (Ahmad, 2020).

Yang-Woo Park, Korea's Minister of Culture, Sports and Tourism, marked the occasion by attending several events, including a special event at Zayed University in Abu Dhabi. His attendance shows that Korean clubs continue to gain momentum as a resource that allows university students to specialize in Korean popular culture. Yang-Woo Park was quoted at the event saying, "Through today's event, we have taken the first step towards elevating the cultures of both sides and have laid the foundation for successfully implementing the Cultural Dialogue 2020" (Salman \& Abubaker, 2020). Korea's YonHap News Agency reported that Yang-Woo Park expected that through exchange programs, "South Korea will seek to carve out a new market for Korean tourism in the Middle East and to expand exchanges between cultural content companies of Korea and the UAE" (YonHap, 2020).

Hally $u$ is a force that has brought economic potential and growth to both countries. It has captured the attention of many Emirati women who are eager to learn more about Korean culture. These Korean clubs in the UAE provide the experiential perspectives that enable female Emirati students to gain intercultural competences. The clubs are in-line with the future goals of the bilateral ties between the UAE and South Korea. It is recommended that further studies look at other countries in the region to see if this phenomenon is prevalent in only the relationship between the UAE and South Korea or if Hallyu has made an impact on other areas as well.

\section{Conclusion}

Hallyu has had a significant impact on young female Emiratis. The Emirati women join Korean clubs at universities in an effort to learn more about the culture. They attempt to immerse themselves in Korean culture by studying Korean at the Korean Cultural Center and watching YouTube videos. The strong interest in Korea coupled with Korean cultural experiences within the UAE is creating culturally competent students who are ready to join the workforce. Arab students capable of speaking Arabic, English, and Korean fluently with a love of Korea will benefit the on-going diplomatic ties between the UAE and Korea.

In celebration of the $40^{\text {th }}$ anniversary of diplomatic ties between the UAEs and South Korea, Korean Minister of Culture, Sports and Tourism Yang-Woo Park and UAE Minister of Culture and Knowledge Development Noura Al Kaabi launched the official UAE-Korea Dialogue for 2020, which will promote cultural exchange and understanding across the fields of media, sports, education, and the arts. This was a step forward in building further economic and trade ties after South Korean President Moon Jae-in's visit to the UAE in 2018, which was reciprocated by Sheikh Mohammed bin Zayed Al Nahyan's visit in early 2019. As Huang (2011) wrote, "For some students, their fun obsession is a means to more serious benefits if they can use their language skills and cultural knowledge to get a job..." Their involvement in Korean clubs is providing the intercultural competence necessary to contribute to the ongoing diplomatic and bilateral ties between the UAE and South Korea. 


\section{Acknowledgments}

We are grateful to the reviewers for their keen insight and thoughtful suggestions. We thank the UAE Korean Cultural Center and the Zayed University Korean Club for their generosity and support. We wish to thank Noura Al Kaabi, UAE Minister of Culture and Knowledge Development and the President of Zayed University as well as Yang-Woo Park, Korean Minister of Culture, Sports, for their support of Korea and UAE cultural relations. Ms. Al Nuaimi would like to thank her family, friends and professors for their constant encouragement at every step of the way (see Appendix 3).

\section{References}

Ahmad, A. (2020, January 20). Cultural dialogue launched to promote UAE-Korea relations. Gulf News. Retrieved from https://gulfnews.com/uae/cultural-dialogue-launched-topromote-uae-korea-relations-1.69129930

Crossman, J., \& Bordia, S. (2012). Piecing the puzzle: A framework for developing intercultural online communication projects in business education. Journal of International Education in Business, 5(1), 71-88.

Hall, E. T., \& Hall, M. R. (1990). Understanding cultural differences. Boston, MA: Intercultural Press.

Hofstede, G. (2001). Culture's consequences: Comparing values, behaviors, institutions, and organizations across nations. Thousand Oaks, CA: Sage.

Hofstede, G. (2019). Compare countries. Hofstede Insights. Retrieved from http://www.hofstede-insights.com/product/ compare-countries/
Huang, C. (2011, June 5). Emiratis 'captivated' by Korean culture. The National. Retrieved from https://www.thenational.ae/uae/ emiratis-captivated-by-korean-culture-1.475822

Jeong, H. W. (2019). Beyond resource diplomacy and economic statecraft: UAE-ROK relations in the 21st century. Asian Journal of Middle Eastern and Islamic Studies, 13(2), 226-245.

Korean Cultural Center. (2020). Welcome to Korean Cultural Center in the United Arab Emirates. Retrieved from http://uae. korean-culture.org/en/7/contents/423

Korean Cultural Center. (2019, September 22). The 7th UAE Korean Speech Contest. Retrieved from http://uae.korean-culture. org/en/556/board/383/read/99473\#mnu1

Salman, N., \& Abubaker, R. (2020, January 20). UAE-Korea Cultural Dialogue kicks-off celebrating 40 years of relations. Emirates News Agency. Retrieved from http://wam.ae/en/details/1395302817441

Swan, M. (2019, January 19). Why Emirati women are now obsessing over South Korean culture more than they are Bollywood or Hollywood. The National. Retrieved from https:// www.thenational.ae/arts-culture/music/why-emirati-womenare-now-obsessing-over-south-korean-culture-more-thanthey-are-bollywood-or-hollywood-1.815282

TOPIK [Test of Proficiency in Korean]. (2020). Korean Proficiency Test. Retrieved from http://www.topik.go.kr/usr/lang/index. do?home_seq=221\&lang=en\#

YonHap News Agency. (2020, January 20). S. Korea, UAE to Celebrate 40th Year of Relationship with Cultural Events. Retrieved from https://en.yna.co.kr/view/AEN20200120008100315

Zayed University. (2018, October 27). Noura Al Kaabi inaugurates the 'Day of Jeonbuk' Festival at Zayed University. Retrieved from https://www.zu.ac.ae/main/en/news/2018/October/kor-fest18. aspx 


\section{Appendix}

Appendix 1. Korean club survey

1. How long have you been in the Korea Club?
a. Less than 1 year
b. 1-2 years
c. 2-4 years
d. More than 4 years

2. Why did you join the Korea Club?

3. What is your Korean language proficiency?
a. Level 1
b. Level 2
c. Level 3
d. Level 4
e. Level 5
f. Level 6
g. Level 7
h. Level 8

4. What is your \#1 reason for your love of Korea?
a. K-Pop
b. K-Drama
c. Food
d. Other (please specify)

5. What is your $\# 2$ reason for your love of Korea?
a. K-Pop
b. K-Drama
c. Food
d. Other (please specify)

6. List your Top 3 favorite Korean Music Artists (Group or Solo)

7. List your Top 3 favorite Korean dramas.

8. List your top 3 Korean food.

9. How long have you been interested in Korea?
a. Less than 1 year
b. $1-2$ years
c. 2-4 years
d. More than 4 years

10. Have you ever visited Korea?
a. Yes
b. No

11. Do you want to visit Korea?
a. Yes
b. No

Appendix 2. Speech script for Korean speech contest

\section{The Drama of Love}

\section{Hello Everyone}

My name is Hessa Al Nuaimi, a Zayed University student majoring in Finance. I am honored and proud to be speaking here today.

I often talk to my Korean friends who live in the UAE, in a Kakao talk group chat. I was curious to find out what taboo topics in the Emirati culture that they would like to know more about, but never got the chance to have a conversation about.

However, I am not sure whether my friends felt like it would be disrespectful to ask, or whether it would offend me but after all it's the year of tolerance, and tolerance is about having conversations, sharing our opinions and opening our hearts to the beauty of diversity.

So, my Korean friends asked me cautiously, "How do you fall in love?... Do you fall in love? ..."

Of course... love, dating and marriage are topics that everyone is interested in and are curious about, especially young people.

In our country, how do men and women meet? when they meet, what do they spend their time doing? Where do they go on dates? And are they able to naturally meet in university and form relationships? Are questions that were often asked. 
Appendix 2. continued

As I listened to my Korean friends' questions, I understood why they may be curious about dating and marriage in the UAE.

It's because when I watch Korean dramas, men and women who meet at blind dates or school can naturally talk, hold hands and go on dates to the amusement park, cinema, cafes and enjoy their time together while eating delicious food and having coffee. However in the UAE, a man and woman cannot go on blind dates and have such relationships.

Then how do we fall in love you may ask?

It is true we are not allowed to date, but that doesn't mean we don't fall in love.

Do you remember the scene in the Korean drama 'Goblin' when the male and female main characters met for the first time in slow motion, in the rain with dramatic music playing in the background?

Well that doesn't happen in real life.

In our culture, when parents, especially the man's mother meets someone who she thinks her son would like and is fit for marriage, the two families meet and start getting to know each other.

It may seem like a big cultural difference but, in both the Emirati and Korean Culture, we respect and love our families; we value and honor them. So, for us we trust that our parents and family would make the right judgment of finding the most compatible person as our partner.

If the families are getting along, the man's family would go to the woman's house and ask for her hand in marriage. When the couple gets engaged, then the bride and groom meet and slowly start to get to know each other and love starts to bloom. Most of the time, before the wedding the couples' dates take place at the bride's house but after the wedding, like any other couple they go on dates to the cinema or a nice fancy restaurant.

As for the wedding ceremonies I've seen in Korean dramas, both men and women celebrate it together in one place, however, in the Emirati culture the men and women's ceremony occur in different venues at different times. The men's ceremony is held during the afternoon while, the women's ceremony is held at night.

So, we do have our different approaches of finding love but after all, love is love and love is universal. Love is tolerance and with tolerance comes love. 
Appendix 3. Message from the student author who won the first place at the Korean Speech Contest

Dear Professors,

Your congratulations wishes warmed my heart. I am honored beyond words for this amazing opportunity and I feel blessed to have my efforts recognized!

I approached Dr. Robyn last year to help guide me with constructing my speech for the Korean Speech Contest. Although my first try was not a victory (but still a great learning experience), she still believed in me and motivated me for my second try. I believe that because of Dr. Robyn's constant encouragement, support and great guidance, that I was able to win 1st place. Dr. Robyn is a great mentor and a great partner to work with on my first ever publication. As my former professor she was always a person who was warm hearted and approachable. I will always be forever grateful and thankful to Dr. Robyn.

Because of my victory, I also had the honors of being the Korean Speaking Host for the Emirati-Korean Cultural Festival which took place in the presence of Her Excellency Noura Al Kaabi The Minister of Culture and Knowledge Development and President of Zayed University as well as His Excellency Park Yang Woo, Minister of Culture, Sports and Tourism Including other Korean Officials in the beginning of this semester at Zayed University.

As a young girl who was known to be quiet and introverted, I am so proud of myself for pushing myself out of my comfort zone and making my success make the noise! I learned so much through this process and I believe that this is just the beginning to bigger and greater achievements! Proud to say I have become a confident young woman who strives for excellence.

Thank you again for all your warm congratulations wishes!

Kind Regards,

Hessa

Hessa Al Nuaimi

College of Business

3rd Year Finance Student 